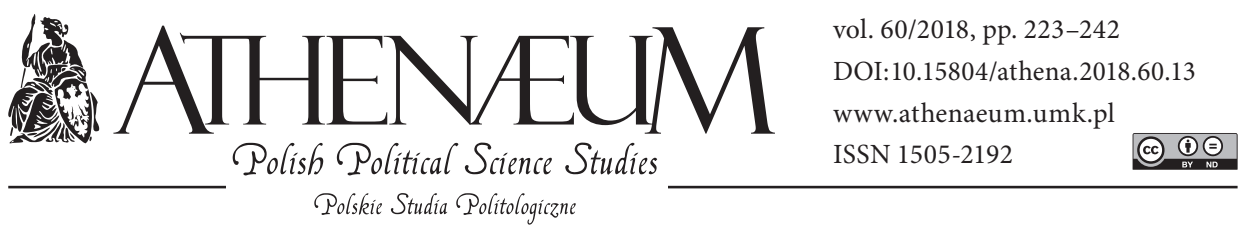

\title{
RUSSIA'S STRATEGIC CULTURE: PRISONER OF IMPERIAL HISTORY?
}

\author{
KULTURA STRATEGICZNA ROSJI: \\ WIĘZIEŃ IMPERIALNEJ HISTORII?
}

Anna Antczak* (1)

\begin{abstract}
The article aims at identifying key elements of Russia's strategic culture and drivers for its change. It starts with a short theoretical overview of the strategic culture concept and different approaches within various theoretical frameworks (liberal, constructive, and post-modern). It focuses on most important determinants of Russian strategic culture, namely history, ideology, geopolitics, systemic issues, and religion. It examines the extent to which Russian policy reflects these determinants.
\end{abstract}

Keywords: strategic culture, Russia, history, ideology, geopolitics, religion

\section{ABSTRAKT}

Artykuł ma na celu wskazanie kluczowych elementów kultury strategicznej Rosji i czynników powodujących jej zmiany. W pierwszej części dokonano krótkiego przeglądu koncepcji kultury strategicznej i różnych podejść w ramach kilku ram teoretycznych (liberalizmu, konstruktywizmu oraz postmodernizmu). Artykuł koncentruje się na najważniejszych determinantach rosyjskiej kultury strategicznej, a mianowicie: historii, ideologii, geopolityce, kwestiach systemowych i religii, a także wskazuje, w jakim stopniu rosyjska polityka odzwierciedla te determinanty.

Słowa kluczowe: kultura strategiczna, Rosja, historia, ideologia, geopolityka, religia

* University of Economics and Human Sciences in Warsaw, Social Sciences Faculty. 
Strategic culture, which is a fairly stable factor affecting the shape of security policy, does not appear once fully formed, but is created through the exercise of leadership, in response to the external security challenges and the influence of internal politics (Baun, 2005). It is also a set of doctrines, behaviors, habits, norms and patterns applied by a given state (Farrell, 2005). Strategic choices of the countries are closely linked to the ideas, norms and beliefs regarding the use of force to achieve certain objectives. However, changing security environment conditions cause a significant re-evaluation in the approaches to the implementation of security policy, including the use of force. The article aims at presenting the main features of Russia's strategic culture as well as answering the question of what are the determinants for its evolution and how does the strategic culture evolve, develop and adapt to the changing security environment? This article, examining current literature on Russian identity and strategic culture, contributes to the overall debate on its determinants and drivers for change. It opens with a short theoretical background on strategic culture concept and then it continues with illustrating determinants of Russian specificity. Its main claim is that Russia's strategic culture has always been based mainly on the idea of hard power, which is connected with a specific approach to patriotism and glorification of history as well as idealization and mythologization of the Russian society's mission in the world in spreading the values of the Orthodox Church. Contemporary Russia's foreign policy should be comprehended considering the conservative heritage as well as philosophical and political perspectives of Nikolai Berdyaev, Vladimir Solovyov and Ivan Ilyin (Ivić, 2016). According to Berdyaev, Russian national self-consciousness was born "within the disputes of Slavophilism and Westernism” (Bierdiajew, 1915). Berdyaev, Solovyov and Ilyin advocate Russia's special and unique purpose and place in the world, Orthodox Christian values and autocracy. These elements are crucial for shaping Russia's strategic culture.

\section{THE CONCEPT OF STRATEGIC CULTURE AND ITS DETERMINANTS}

It is claimed that "world culture shapes the way states generate military power: norms of conventional warfare provide the template for military organization, and norms of humanitarian law define what is morally acceptable in military operation" (Farrell, 2005). The "cultural" approach to strategy originates from sociologists and anthropologists (Margaret Mead, Mary Douglas, Claude Levi- 
Strauss and especially Clifford Geertz, whose definition of culture had a great influence on developing the theoretical concept of strategic culture) who tried to find and explain the link between culture and behavior. It was a basis for the cultural approach in politics (the works of Gabriel Almond and Sidney Verba). Consequently, there started to appear studies connecting and explaining the role of culture and states' behavior (Ann Swidler, Max Weber, or Talcott Parsons). Finally, it was Jack Snyder who introduced cultural element into security studies by investigating Soviet nuclear strategy. He asserted that "as a result of the socialization process, a set of general beliefs, attitudes, and behavior patterns with regard to nuclear strategy has achieved a state of semi-permanence that places them on the level of 'cultural' rather than mere policy" (Snyder, 1977).

Therefore, from the beginnings of the 1980s, there emerged a lot of significant studies concerning the notion of strategic culture and it is common to divide the development of this concept into three "generations". The "first generation" attributed to realism/neorealism, was prescribed to the work of Jack Snyder, as well as Colin Gray and Kenneth Booth who noticed the association between cultural aspects of strategy as such and nuclear strategy. Strategic culture was defined as "modes of thought and action with respect to force, which derives from perception of the national historical experience, from aspirations for responsible behavior in national terms [as well as...] the civic culture and way of life. [...] It provides a milieu within which strategy is debated" (Gray, 1981), being at the same time an independent determinate of strategic policy patterns (Lantis, 2009). The "second generation" arose from critics based on the conviction that previous strategic cultural models lacked the clear separation of dependent and independent variables and its representatives claimed that strategic culture is "socially constructed by knowledgeable practice" (Wendt, 1992). Structural constructivists (Robert Keohane, Peter Katzenstein and Stephen Krasner, but also Kenneth Waltz) believed that inter-subjected structures like norms, culture, identity and ideas influence states' decision-making processes and thus have reflection in their behavior. The "third generation" is attributed to Alistair Johnston and his cognitive symbolism, according to which strategic culture is "an integrated system of symbols (i.e., argumentation structures, languages, analogies, metaphors, etc.) that acts to establish pervasive and long-lasting grand strategic preferences by formulating concepts of the role and efficacy of military force in interstate political affairs, and by clothing these conceptions with such an aura of factuality that the strategic preferences seem uniquely realistic and efficacious" (Johnston, 1995). He also believes that strategic culture determines boundaries 
of behavioral choices, which is achieved by "shared assumptions and decisions rules that impose a degree of order on individual and group conceptions of their relationship to their social, organizational or political environment". For the purposes of this article, strategic culture is defined as a set of "shared beliefs, assumptions and modes of behavior, derived from common experiences and accepted narratives (both oral and written), that shape collective identity and relationships to other groups, and which determine appropriate ends and means for achieving security objectives" (Kartchner, 2006).

As far as the sources of strategic culture are concerned, they can be generally divided into three groups: physical (geography, climate, natural resources, generational change, technology), political (historical experience, political system, elite beliefs and military organizations), and social or cultural (myths and symbols, defining texts; Lantis, 2009). Probably, in some cases, also population should be taken into consideration, which will be especially important for Russia (mass army, disrespect for life, etc.) as well as values and religion. The carriers of the strategic culture and its values are people and institutions they establish: mostly political leaders, political parties as well as government and military-related institutions and organizations. Moreover, there are four main determinants (areas) shaping the strategic culture, especially in military terms: goals of force implementation, methods of force implementation, authorization of force implementation at the national and international levels, and preferred mode of cooperation with respect to security (Meyer, 2005). They are also related to other constraints like institutional restrictions or defense capabilities limitations (Antczak, 2012).

It is also worth considering how the above-mentioned determinants may change. In other words, which factors cause the re-evaluation of the strategic culture? In Meyer's (2005) opinion, there function three main mechanisms: a change in the perception of risks, institutionalization - the process of structures and socialization of the security institutions, and lessons learned from the direct involvement in the war and its distribution among the society. Therefore, strategic culture changes whenever we deal with "dramatic events or traumatic experiences which discredit thoroughly core beliefs and values" (Berger, 1998). Lantis (2009) ads that foreign policy may also be the source of such a change when primary tenets of strategic thought come into direct conflict with one another. 


\section{LEGACY OF RUSSIAN STRATEGIC CULTURE}

"Traditional Russian strategic culture - that of Imperial Russia from its emergence as a state in the middle of the last millennium through most of the existence of the Soviet Union into the late $1980^{\text {s }}$ - has been one of the most martial and militarized such cultures in history" (Ermarth, 2009). If this is the case, contemporary Russia's strategic culture is to a certain extent set in this heritage. The huge question is about this very extent. It is also worth noting that Russian strategic culture is a mixed product of political culture (with respect to the understanding of such concepts like power, authority and leadership related to strong authoritarian heritage), foreign policy (perception of the outer world as well as Russia's role and status), attitude towards military tools (the role of military potential in strategy and politics as well as willingness to use force) and economic policy (resources treated as a source of power - primarily manpower, currently - gas and oil), which all in turn are influenced by strong Russian geopolitics, specific attitude towards the state's and nation's history and role as well as values resulting from religion.

The above-mentioned robust militarism is a result of the conditions in which Russian state emerged and expanded - constant necessity of waging wars defensive at the beginning and offensive (expansive) in later periods (Ermarth, 2009). The necessity to preserve the unity of the multiethnic and multicultural state on such huge and diversified territory with no stable borders resulted in continuous fear and sense of vulnerability which was covered by the need for further expansion and thus, militarization. Nevertheless, an interesting observation is that in such strategically "militarized" country, military contribution (in terms of direct or active military intervention) in politics is very low (Ermarth, 2009). This element may also influence today's strategy and preference in nondirect, covert actions (like "little green men" used in Ukraine). Disregard for causalities and soldiers' living conditions was (and despite professionalization and modernization of Russian armed forces, to some extent still is, at least in the sub-consciousness of the older generations) a characteristic feature of Russian strategic culture, as it was presumed that manpower is endless and mass army can always be renewed.

Russian history as well as traditions related to the Orthodox Church play an important role in shaping the strategic culture. First of all, for a long time, Russian strategic culture was built on the status of the great power (Cassidy, 2003) and in a sense, it is still the case. Thus, the "big-war paradigm [...] and 
the continued embrace of a conventional and predictably symmetric approach" (Cassidy, 2009) accompanied Russian strategy until the mid 1990s. Late 1990s brought in a slow change, yet the continuity of the "traditional" culture can still be observed. Russian military is adapting very slowly to the challenges of the contemporary type of conflict. As rightly claimed by Cassidy,"the military organizations of great powers are normally large and hierarchical institutions that innovate incrementally, if at all" (Cassidy, 2009). Combined arms doctrine for long was the preferred method of Russian warfare and it still would be or even is whenever applicable (when its use is possible and presumed to be successful). Other instruments of security policy, especially propaganda, seem to adjust quicker and better, but they are still applying imperial philosophy rather than the contemporary one, nonetheless, it seems to be effective. Russia's imperial ambitions may be nineteenth century in nature, but propaganda is one of the most important tools of the "soft power", which in fact is redefined by Russia into "hard power in a velvet glove" (Van Herpen, 2015). Secondly, backing to imperial times, Russia was always assertive as far as the control over its territory and zones of influence is concerned. As observed by Cassidy, imperial Russia conducted a "messianic crusade to expand, "civilize» and russify a multinational empire" (Cassidy, 2009). Ideological consolidation was a main motto for the Soviet domination over Eastern Europe, Caucasus and Central Asia in order to maintain the unity of the lands conquered throughout the imperial times. Russia, in turn, has tried to restore this empire after the collapse of the Soviet Union and regain the status of the great power, which is perceived as a due position. "The "patrimonial mentality embedded in the Russian psyche» which posits that everything inherited from previous epochs is «inalienable property» argues against accepting the separation of the former republics as a fait accompli" (Cassidy, 2009). Russia's position arose from military mass power and related geography (the size of the country) rather than from cultural, economic or even purely political issues. "Russia's claim to be a world power has traditionally rested on military prowess, and the temptation is to resort to this expedient once again" (Pipes, 1997). Knezys and Sedlickas'(1999) belief that Russia's central strategic aim is to restore the former empire and the desire to rebuild solid zones of durable influence seems to be even stronger: "The goal of preserving a «Great Russia» was always at the heart of the Russian Federation's efforts. The basic contours of this policy had remained unchanged since tsarist times with only the tools of modern warfare being added to the methodology. All the old ramifications of empire went with it and, in essence, hegemony by force of arms remained its key ingredient". Such 
approach is not groundless, as every political move is accompanied by adequate military argument, not to leave any doubts as to seriousness of Russiass intentions on the international arena.

\section{DETERMINANTS OF RUSSIA'S STRATEGIC CULTURE}

\section{History}

Russia is characterized by aggressive "historical policy" being a base of its super-power and imperial ideology (Bieleń, 2006). Contemporary Russia has never formally broken the vows with the Soviet Union (it has never proclaimed independence and did not exit the USSR). As noted by Graham Smith, cult of history takes an important place in shaping Russian identity and the past serves as a typical argument in politics (Smith, 1999). To many Russians, even the very remote history is a source of mystical strength and wisdom (Podberezsky, 1999), showing the path and solutions to current problems. Russian identity is based more on the consciousness of the past than the present. In Russia, history is created by political elites and historical memory is used to identify its power. Aggressive historical policy concerns manipulation of facts, evaluations and interpretations according to authority's needs, which are sometimes at the edge of political provocation (Bielen, 2006). Russian society tends to have very selective historical memory, remembers only what is preferred (Etkind, 2004) and wants to defend what is perceived as historical truth. Russian sticking to history is a result of disappointment with the transformation period and history becomes the only source of pride and faith (symbols of the former imperial times became a basis for ideological fundaments). Idealized version of history and instrumental treatment of the past serve as a tool for self-identification based on manipulation. It is accompanied by Russian complexes of inferiority and alienation being a result of the sense of injustice and treason, and thus reluctance toward the outer world. Myths and legends based on a very strong historical memory, which is often modified and used for propaganda issues - as it is the case of the Great Patriotic War, combined with the messianic belief in the uniqueness of the Russian nation and state as well as the conviction of being the only defender of the Orthodox Church values, gives an explosive mix as a foundation for Russian strategic culture. 


\section{Geopolitics}

Another important factor is geography and geopolitics. Russian national identity is to a large extent based on its geography, which is perceived as a part of history in ideological sense. All Russian "geographic elements" which helped defend the country are now glorified and constitute a part of the mythical continuity of the primary national spirit. This resulted in the process of sacralization of the country's territory both in religious (the holiness of the Orthodox soil) and secular terms (the ancestral heritage and national traditions). Therefore, defending territory is crucial to the strategic culture and takes a central place; all other aspects are subordinate in nature. Territorial-centrism in Russian political and strategic culture implies striving for restoration of geopolitical power (to rebuild historical national pride and dignity). In the light of the above, Russian military engagement in Chechnya, Georgia and Ukraine should not be surprising - it is a part of a bigger plan - regaining what is perceived as righteously belonging to Russia and whose lack is a threat to Russian raison d'état (defined as defending of historically determined territory which grants state's integrity, restoration of Russian pride and performance of historical and religious duty). There arises an important question if it is neo-imperialism or specific nationalism defined as defending what is perceived as being rightfully Russian (by history, tradition and as defined as "the Russian world"). Security of the country is also perceived in terms of having the zones of influence in the closest neighborhood, which is indispensable for country's restoration of power. Geopolitically conditioned, Russian security evokes concerns among neighboring countries which perceive Russian behavior as neo-imperial and aggressive in nature. Geography and resulting cultural and traditional issues play an important role in building Russian identity, thus also its strategic culture. Therefore, contemporary Russia has a double but inseparable civilizational and geopolitical identity due to belonging to the eastern part of European Christian civilization and Eurasian territorial location.

Systemic issues

Russian strategic culture to a large extent is determined by imperial and authoritarian character of its statehood's nature as well as power imperative related to behavior in the international arena (Broda, 2008). As stated by A. Kara-Murza and L. Polakow (1994), internal and external expansion of power is the main 
driver for state and history building processes with the continuous chain of ups and downs. G. Fiedotow (1991) also indicates that Russian historical development was opposite to the Western one - from freedom to enslavement: "it was dictated by a new task - creating an empire on a poor economic basis; only the complete and mass concentration of forces, discipline and terrible sacrifices, there could exist this impoverished, barbaric and endlessly expanding country".

Political culture resulting from authoritarian character of the state contributed largely to the emergence of the strategic culture. Russian version of authoritarianism is built on military grounds (values), "martial" rules and as pointed out by Fritz Ermarth (2009), "it is grounded on the principle of kto-kovo" (literally 'who-whom', i.e., who dominates over whom in terms of power hierarchy). Another characteristic feature of political culture is manipulation, tendency for intrigues and conspiracies, not necessarily negotiations, discussions, voting or solutions based on legal procedures. As aptly summarized by Fritz Ermarth (2009), "Russia regards the features of normal democratic life - parties, parliament, a meaningful press, election campaigns - not as the enabling conditions of a legitimate polity, but as instruments to be manipulated, controlled, or combated for the benefit of the central authority". Perhaps, this gives an explanation why Russian political elites have strong inclinations for manipulation and propaganda both with respect to foreign (the international community and their societies) and internal policy (own society) - the heirloom of authoritarianism, fear of the enemy and the need to control everything. Foreign countries were always divided by Russia into four basic pragmatic categories: perforce temporary allies, useful tools to be manipulated, non-important objects, and enemies (Ermarth, 2009). Effective realization of foreign policy within the above-mentioned conditions of political culture required Russian political elites to fully master diplomatic skills, which they did, using manipulation and craftiness as well as national pride and messianic attitude at the same time. This results from two contradictory forces responsible for the development of Russian strategic culture - superiority and inferiority complex at the same time. Superiority complex is fed by geography, history (especially by winning the Great Patriotic War and Russia's role in "saving the world") and messianism, while inferiority complex is a result of the lost superpower position and alienation. Therefore, Ermarth (2009), claiming that "in rhetoric and action, Russian foreign policy culture has often expressed a puzzling combination of contradictory attitudes: defensiveness bordering on paranoia, on one hand, combined with assertiveness bordering on pugnacity, on the other", seems to have a point there. Russia is generally risk-averse and undertakes 
military actions when the security fear is awoken. It does not have to be a direct threat; it is enough that safety buffers are uncertain. In other cases, Russia prefers deterrence than direct involvement in conflict. Recently, Russia also started to use force in order to demonstrate its super-power position and ability to participate in shaping the world order (reestablishing the zones of influence). Nevertheless, Russia's military engagement is calculated to be failure-free (not to repeat the mistakes of the First Chechen War or the intervention in Afghanistan).

The way Russians perceive internal situation of their state is also specific. It is directly and strongly connected or even dependent on the perception of the country's position in the world (Broda, 2015). Thus, military power plays such a significant role in Russia's strategic culture. Mass warfare and total mobilization of the state are inherited from the imperial (but also Soviet) times and originate from social and geographical conditions. Men were always available, so they were not treated as a valuable tool, because this tool could have always been replaced by another one. Therefore, Russia did not pay much attention to training, individual equipment or professionalization of its armed forces. It has been changing slowly for the last 10-15 years, however the process is very slow and concerns training and equipment rather than the value of soldiers' life.

\section{Ideology}

Many philosophers, such as Nikolai Berdyaev, Alexander Solzhenitsyn, Vladimir Solovyov or Ivan Ilyin, indicated the uniqueness of Russian social structure. Contemporary Russian identity built upon the conviction of exceptionality combined with common traditions, sentiments and experiences reflects much of this philosophy, so is the strategic culture. Paternalism of authorities and the need of strong leadership are traditional systemic features in Russia. Tradition dictates almost servile attitude of the individual towards collectivity as well as resulting commitment to common ownership, which is not necessarily the legacy of socialism (Bieleń, 2006). Russia has also strong history of authoritarian models due to the necessity of control over the huge territory inhabited by different nations, which could be granted only by strong authority. In time, this led to mythologization of leadership and consequently - its sacralization. Therefore, contemporary strategic culture is based on the conviction about infallibility of the authority. Common perception of threats was an additional bonding factor for the society which perceived its security as being the greatest value (Kokoshin, 1996) and a key to comprehend Russian contemporary strategic culture (clearly 
identified allies and enemies). This issue is strictly connected with the very understanding of security, which is related not only to the country itself, but also the "security ring", i.e., the closest neighborhood (Russia's security concept is based on the conviction that state's borders do not coincide with security borders, but encompass the whole post-Soviet space), the zone of influence and (military) presence in important regions of the world. Only the full combination of all these elements grants Russia security and a proper position (of a super-power) in the world at the same time. Russian military presence in other countries is supposed to support regional stability and balance of power as well as prevent escalation of crises (Bieleń, 2006).

Russian strategic culture is also deeply rooted in political nationalism, which shapes or even dictates many ways of the state's behavior. Lev Gudkow and Boris Dubin (2005) characterize Russian political nationalism as:

- conviction about Russians' superiority;

- militarism - special role of war and armed forces in constructing the state and national identity structure;

- symbolic character of single highest authority resulting from the idea of organic unity of Russians;

- isolationism and anti-West attitudes manifested in repressions towards the society and search for inner and outer enemy.

An important issue is that the specificity of Russian nation and state has attributed to Russian nationalism state, imperial and superpower character (Pozdniakow, 1994; Bierdiajew, 1997). Thus, the aim of Russian political nationalism has always been the protection and realization of subjectively perceived state interests and not the ones of the nation (Wierzbicki, 2000). This is the reason why it played an important role in shaping the strategic culture which can be characterized by militarism, reluctance towards peaceful resolution of conflicts, authoritarianism, concentration of central authorities, search for inner (Caucasians, Asians) and outer (the West) enemies in order to build "we - them" binary oppositions.

Russian political and strategic culture is also built on the project of russkij mir (the Russian world) which strengthens the super-power aspiration. Russian strategic culture is marked by a specifically defined national interest and realistic paradigm related to rivalry, domination and spheres of influence. Russian imperialism is very specific as it is strongly dominated by nationalistic ideology imposing isolationism and protection from external influence aimed at the defense of the "Russian world" with its own language, identity, history, 
religion, culture (with East-Slavonic national civilization concept) and traditions which can be threatened by the outer world. Many scholars have built various theories trying to explain the complexity of the "Russian world concept" and its influence on Russian identity. The most comprehensive approach is "cultural Russianness" suggested by Natalia Kosmarskaya (2011) in which Russia and its culture play the role of a "spiritual homeland" (Flynn, 2007). It is however necessary to remember that Russian identity is a hybrid one, being a mixture of Russian and local identities, which adds another complexity to the process of shaping of political and strategic culture of Russia. Summing up, the main drivers which shape Russian identity and mentality and thus influence the creation of the strategic culture (constituting its background), is the conviction about Russia's exceptionality and eternality as well as playing the role of the guardian of the universal order.

Huge role is attributed to propaganda which is based on images, convictions, stereotypes rooted in mass social mentality and fears, which Kremlin ideology refers to building messages related to the state's exceptionality in terms of religious issues, nationalist or messianic ideology as well as civilizational and cultural heritage and geography. Political and strategic culture of contemporary Russia was also "operationally" influenced by the works of Alexander Dugin and Alexander Panarin (who may also be considered as fathers of Russian contemporary propaganda ideological assumptions) which were designed to be an answer to Zbigniew Brzeziński's concept presented in The Grand Chessboard and proposed a concept of Eurasian anti-American coalition. Dugin inspired anti-Americanism and anti-Westernism and inculcated these ideas in the heads of the authorities and then, through the "hands" of the authority, in the heads of the society. The whole imperial formula of neo-Eurasians may not have many followers in Russia, but very common is the accompanying ideology based on the conviction that the Western philosophy as such is a threat to Russia as a nation and super-power (Potulski, 2015).

\section{Religion}

Finally, there is a need to mention the role of the Orthodox Church as a binder for Russian ideology (Wierzbicki, 2008). Russian Orthodox Church stands as a defender of traditional values, which is the Kremlin's tool to propagate messianic ideology and glorifying the state. Being deeply nationalist, homophobic and denying Western values, it also supports Russia's narrative based on his- 
torical memory (Antczak, 2017). Ideological vacuum in contemporary Russia is filled in by mythologized history on the one hand, but mostly by religion (the Orthodox Church). Not only does it serve as a spiritual guidance, but also or even mostly, it becomes an ideological background for national authorities (politicization of religion). The Orthodox Church enhances the renaissance of the "culture of obedience" (Bieleń, 2006), which also determines society's attitude towards authorities and this in turn strengthens the central power. Religious issues are strongly connected with the already mentioned specific messianism, which comes to the specific mission that Russian nation has to fulfill nationally and internationally as "the heir of legendary religious and imperial tradition" (Ermarth, 2009). This issue served to legitimize expansion and arousing the conviction about cultural and moral superiority based on spreading religious values of the Orthodox Church.

Moreover, superpower attempts and all efforts aiming at increasing power are perceived as an obligation for the citizens and a political imperative for state authorities, which is morally and even religiously motivated and supported (Broda, 2015). Within the Orthodox Church ideology which influences mentality and socio-political awareness of the society, the power status means "nations self-awareness of Russians being responsible for stopping Antichrist and liable for the whole society and the superpower-state" (Lazari, 1995). The myth of power associated with authority relates to the myth of Russia's strength and exceptionality, which in turn influences social awareness concentrated on the faith in omnipotence of authority (Kowalska, 2013). Afanasjew (2005) goes even further claiming that "mythical thinking is not only a rule, but also the content of social consciousness". This phenomenon is also connected with the cult of personalized and sacralized central authority, which is one of the most important elements of socio-political system (Broda, 2015). In such circumstances, Russian political and strategic culture may tend to be more authoritarian than democratic in nature. Even though Russian political system is democratic in theory, it arose from authoritarian tradition and political culture of Russian society as well as from the necessity to create a strong central authority to introduce systemic changes and prevent the dissolution of the whole state (Zieliński, 2005). Russian system is called differently by various scholars: "delegative democracy" (Kubicek, 1994), "formal democracy", "plebiscite democracy" (Migranian, 2004), "steered or controlled democracy", "manipulated democracy", "patronage democracy”, "illiberal democracy", "half democracy”, "electoral democracy” (Lukin, 2001), and "market Bolshevism" (Nunn \& Stulberg, 2000). The way democracy is 
executed in Russia influences political and strategic culture mostly in the way the decisions are made. The restoration of the statehood, of social identity and self-consciousness based on national pride, historical memory and religious values has become a political priority. To achieve this, centralization of power, and strengthening of this central authority were most important elements as well as establishing of stable systemic institutions and the Orthodox Church was supporting these processes.

\section{STRUGGLE WITH THE PAST - RUSSIA'S STRATEGIC CULTURE IN THE LAST TWO DECADES}

Attempts to change Russian political and strategic culture undertaken during Yeltsin's presidency turned into fiasco. Without analyzing all other weaknesses and obstacles of the Yeltsin period, it is perceived by Russian society as a time of Russia's weakness, disregard in international relations and deepening of the inferiority complex due to the loss of the super-power status and influence on global affairs. While Yeltsin's government tried to put Russia on a more Westernlike democratic path, the country was slowly turning into chaos and imperialist sentiments started to revive. Finally, the period of Yeltsin's presidency started to be called the Yeltsin's Time of Troubles, referring to the Time of Troubles from the turn of the $16^{\text {th }}$ and $17^{\text {th }}$ century. The attitude towards these events is well described by Aleksandr Golts (2004) and Stephen Blank (2005), whose very titles of monographs are meaningful. Today's strategic culture is also an answer to these times - restoration of Russian greatness, which is society's expectation towards the government (in this case - Vladimir Putin specifically ${ }^{1}$ ).

Present strategic culture is shaped by the post-Yeltsin "reflection": resentments about the collapse of the Soviet Union and loss of super-power status guaranteeing "appropriate" international position; perception of the West (especially NATO, due to its enlargement, and the US, due to the intervention in the Balkans and general hegemonic posture) as a threat, specifically with respect to taking over Russian traditional spheres of influence; desire to reestablish Russian power and respectability as well as restore military capabilities and power to be able to influence the shaping of international order and to participate in global governance. As already mentioned, Russian strategic culture is also mounted on

\footnotetext{
${ }^{1}$ This expectation is based on the society's strong reliance on the mighty leader.
} 
the threat perception which is related to the generally perceived West, especially the United States. Orange Revolution in Ukraine as well as the Maidan was perceived as a double threat - not only in terms of the West intruding traditional Russian spheres of influence, but also regarding the fear of possible spillover of the revolutionary sentiments on Russian state (Skak, 2016).

Finally, Russian strategic culture can be characterized both by an "almost obsessive perception of a general threat towards Russian sovereignty and territorial integrity, and by great power aspirations as a response" (Eitelhuber, 2009). Therefore, the need for armed forces modernization, not only in terms of its professionalization (shift from conscription and mass forces towards smaller and well-qualified ones), but also with respect to armament and materiel is widely agreed upon, but theory is far from practice. In reality, traditional patterns and way of thinking is present at many levels of Russian military leadership and the change proceeds very slowly. Russia learned a lot from its failures in Afghanistan and Chechnya and adapted its strategy to better fit asymmetric conflicts in which it has to face an adversary of the pre-industrial type or at least whose forces are more of the guerrilla type, are dispersed and highly motivated (like second Chechnya war and conflict with Georgia or Ukraine). Lessons learned from Chechnya and Afghanistan concerned two things. First, the approach towards asymmetric conflict with conventional doctrine and conventional forces and second, propaganda-related information warfare which constituted a kind of advance action months before the actual military engagement (it was tested in Georgia, improved and employed again in Ukraine).

Summing up, due to "a fantasy-based disappointment that the United States and the West had not rescued Russia, especially from its economic crisis; and also by a reality-based perception that Western leaders, advisors, and greedy businesses were significantly responsible for the «bandit privatization and capitalism» that impoverished most Russians and created a hated class of wealthy, politically powerful oligarchs" (Ermarth, 2009), Russian traditional strategic culture was reborn. Fundamentals such as competitiveness, assertiveness, demandingness and combativeness started to play a central role. Such attitude is based on Russian nationalism, self-centrism and fear of the outer world as well as the strategy based on the philosophy of binary oppositions (especially "we - them" and "our - foreign/alien") and the sense of mission to balance the US-centered Western world and values. This change, or rather rebirth, was conceivable due to huge economic growth based on Putin's resources policy (Russia as an "energy power"). This in turn enabled the reappearance of militarist attitude in the politi- 
cal discourse, public debate and politico-strategic culture which is combined with nuclear deterrence rhetoric (nuclear weapon play an important role in the overall Russian strategy).

\section{CONCLUSION}

As stated by Alexei Arbatov (1994) and Geoffrey Hosking (2002), Russian superpower was constructed on three basic elements which shape the contemporary strategic culture:

- state-managed economy subordinated to the main goal of securing military power (in order to win wars),

- hierarchical - authoritarian or totalitarian political system based on messianic ideology,

- building an empire basing on territorial expansion.

Nevertheless, today's Russian political and strategic culture results more from nationalist ideology than typically imperial ambitions. It is based on the primacy of the state over the human being who is enslaved, permanent expansion guided by the vision of religious salvation of the Russian nation and generally all mankind as a legitimizing factor (territorial growth was interpreted in terms of growing of the "Holy Land"). At the same time, Russia is struggling with strong internal separatist tendencies, which results in the country's reluctance towards any form of sovereignty or real autonomy of its republics, especially in terms of key political and economic issues.

Nowadays, Russia's strategic culture is strongly based on pragmatism and nostalgia as well as confrontational attitude towards the West resulting from ideological clashes and historical prejudices. It also relates to the psychological complex based on the sense of threat of the vital interests because buffer countries (zones), being a traditional sphere of Russian political influence, are leaning towards the West (Ukraine, Georgia). Russia is also vulnerable to the phobia of losing the status of one of the most important global decision-makers (omnipresence) and nowadays, Russian political leaders refer to the concept of the balance of power that is more confrontational than cooperational (at least in rhetoric).

Summing up, Russian strategic culture is built on metanarratives which were created basing largely on history and its glorification, ideology based on authoritarian heritage resulting in the cult of power as well as collectivity 
being put before the individual, which is also reflected in the approach to the armed forces and their instrumental treatment. Strategic culture is also rooted in Russian attachment to geopolitics and sacralization of the territory which is perceived as Russian "by roots" (this is also true for the zones of influence towards which Russia claims its rights). Expansionism linked to messianism (with respect to values and religion) also plays an important role in shaping contemporary ideology, thus the strategic culture as well. The concept of binary oppositions is present in the way Russia is formulating its metanarratives. The opposition of "we-they" is a basis for building social consciousness of the nation, who is longing for restoration of Russian super-power position. Such status is believed to be due not only because of the mythologized role Russia played in winning the Great Patriotic War, but also owing to the belief of being a chosen nation. Deeply rooted sentimentalism and slavinism (taking the form of specific nationalism) are also the sources of strategic thinking aiming at restoration of Russian power and "rightful" position in the world. These attitudes are additionally supported and "legitimized" by the Orthodox Church, giving Russian strategic culture the "spiritual" dimension. Finally, Russia's strategic culture is built on both superiority and inferiority complex resulting from longing for the power status and feeling of injustice and exclusion. This gives an extraordinary mixture of historical, ideological, geopolitical and deeply emotional factors which are all rooted in mythologized and glorified past events and sentimentalism making Russia's strategic culture sometimes difficult to understand and its specific actions undertaken basing on this culture - very obvious on the one hand, but difficult to predict on the other.

\section{ReFERENCES:}

Afanasjew, J. (2005). Groźna Rosja. Warszawa: Oficyna Naukowa.

Antczak, A. (2012). Role międzynarodowe Unii Europejskiej. Aspekty teoretyczne. Warszawa: Vizja Press \& IT.

Antczak, A. (2017). Russian Phobia or a Real Threat? Propaganda-Related Elements of Russian Information Warfare in Ukraine and Their Implications for Euro-Atlantic Security. Athenaeum. Polskie Studia Politologiczne, 56.

Arbatov, A. (1994). Russia’s Foreign Policy Alternatives. International Security, 18(2), $5-43$.

Baun, M. (2005). How Necessary is a Common Strategic Culture? Oxford Journal on Good Governance, 2(1), 33-37. 
Berger, T.U. (1998). Cultures of Antimilitarism: National Security in Germany and Japan. Baltimore, Maryland: Johns Hopkins University Press.

Bieleń, S. (2006). Tożsamość międzynarodowa Federacji Rosyjskiej. Warszawa: Aspra-Jr. Bierdiajew, M. (1915). Slavophilism and the Slavic Idea. Retrieved from: http://www. berdyaev.com/berdiaev/berd_lib/1915_202.html.

Bierdiajew, M. (1997). Nowe średniowiecze. Warszawa: Antyk.

Blank, S.J. (2005). Potemkin's Treadmill: Russian Military Modernization. In: A.J. Tellis, \& M. Wills (eds.), Strategic Asia 2005-2006: Military Modernization in an Era of Uncertainty (pp. 175-208). Seattle: National Bureau of Research.

Broda, M. (2008). Putinowskie antidotum. In: A. Stępień-Kuczyńska, \& S. Bieleń (eds.), Rosja w okresie prezydentury Władimira Putina (pp. 11-59). Toruń: Adam Marszałek.

Broda, M. (2015). Mocarstwowy imperatyw i imperialno-autorytarne fatum współczesnej Rosji? In: S. Bieleń, \& A. Skrzypek (eds.), Rosja: rozważania imperiologiczne (pp. 19-38). Warszawa: Aspra-Jr.

Cassidy, R.M. (2003). Russia in Afghanistan and Chechnya: Military Strategic Culture and the Paradoxes of Asymmetric Conflict. Carlisle: Strategic Studies Institute, Army War College.

Eitelhuber, N. (2009). The Russian Bear: Russian Strategic Culture and What It Implies for the West. Connections: The Quarterly Journal, 9(1), 1-28.

Ermarth, F. (2009). Russian Strategic Culture in Flux: Back to the Future? In: J. Johnson, J.A. Larsen, \& K.M. Kartchner (eds.), Strategic Culture and Weapons of Mass Destruction: Culturally Based Insights into Comparative National Security Policymaking (pp. 85-96). New York: Palgrave Macmillan.

Etkind, A. (2004). Hard and Soft in Cultural Memory: Political Mourning in Russia and Germany. Memory-History-Democracy, 16, Special Issue, 36-59. DOI: $10.1162 / 1526381041887439$.

Farrell, T. (2005). World Culture and Military Power. Security Studies, 14(3), 448-488.

Fiedotow, G. (1991). Russia's Faith and Sins [translation from Russian]. Vol. 2. Sankt Petersburg.

Flynn, M. (2007). Renegotiating Stability, Security and Identity in the Post-Soviet Borderlands: The Experience of Russian Communities in Uzbekistan. Nationalities Papers, 35(2), 267-288. DOI: 10.1080/00905990701254359.

Golts, A. (2004). Армия России: 11 потерянных лет. Moskwa: Zakharov.

Gray, C.S. (1981). National Style in Strategy: The American Example. International Security, 6(2), 21-47. DOI: 10.2307/2538645.

Gudkow, L., \& Dubin, В. (2005). Своеобразие русского национализма. Pro et Contra, $2,6-24$.

Hosking, G. (2002). Russia and the Russians: From Earliest Times to the Present. London: Penguin Books.

Ivić, S. (2016). The Clash of Civilizations? Russia vs. the West, or Conservative vs. Liberal Political Paradigms. NDC Magazine Vox Collegii, 13. 
Johnston, A.I. (1995). Thinking About Strategic Culture. International Security, 19(4), 32-64. DOI: 10.2307/2539119.

Kara-Murza, A., \& Polakow, L. (1994). Reformer: Russians About Peter I. Anthology. Iwanowo.

Kartchner, K.M. (2006). Weapons of Mass Destruction and the Crucible of Strategic Culture. Defense Threat Reduction Agency.

Knezys, S., \& Sedlickas, R. (1999). The War in Chechnya. College Station: Texas University Press.

Kokoshin, A.A. (1996). The New Russia: Inheritance and Perspectives. PRIF Report No. 43. Frankfurt/M.

Kosmarskaya, N. (2011). Russia and Post-Soviet 'Russian Diaspora': Contrasting Visions, Conflicting Projects. Nationalism and Ethnic Politics, 17(1), 54-74. DOI: 10.1080/13537113.2011.550247.

Kowalska, M. (2013). Rosyjski mit władzy a kult jednostki. Poznańskie Studia Slawistyczne, 5, 143-156. DOI: 10.14746/pss.2013.5.10.

Kubicek, P. (1994). Delegative Democracy in Russia and Ukraine. Communist and PostCommunist Studies, 27(4), 423-441.

Lantis, J.S. (2009). Strategic Culture: From Clausewitz to Constructivism. In: J. Johnson, J.A. Larsen, \& K. Kartchner (eds.), Strategic Culture and Weapons of Mass Destruction: Culturally Based Insights into Comparative National Security Policymaking (pp. 33-52). New York: Palgrave Macmillan.

Lazari de, A. (1995). Rosyjska mentalność. Katowice: Śląsk.

Lukin, A. (2001). Electoral Democracy or Electoral Clanism? Russian Democratization and Theories of Transition. In: A. Brown (ed.), Contemporary Russian Politics: A Reader (pp. 530-545). Oxford: OUP.

Meyer, C. (2005). Convergence towards a European Strategic Culture? A Constructivist Framework for Explaining Changing Norms. European Journal of International Relations, 11(4), 523-549. DOI: 10.1177/1354066105057899.

Migranian, A. (2004). What is 'Putinism'? Russia in Global Affairs, 17(2), 28-44.

Nunn, S., \& Stulberg, A.N. (2000). The Many Faces of Modern Russia. Foreign Affairs, 79(2), 45-62. DOI: $10.2307 / 20049640$.

Pipes, R. (1997). Is Russia Still an Enemy? Foreign Affairs, 76(5), 65-78. DOI: $10.2307 / 20048200$.

Podberezsky, I.V. (1999). Between Europe and Asia: The Search for Russia’s Civilizational Identity. In: G. Chufrin (ed.), Russia and Asia: The Emerging Security Agenda (pp. 33-51). Oxford: OUP.

Potulski, J. (2015). Rosyjskie koncepcje geopolityczne jako wyraz poszukiwań formuły imperialnej? In: S. Bieleń, A. Skrzypek (eds.), Rosja: rozważania imperiologiczne (pp. 39-65). Warszawa: Aspra-Jr.

Pozdniakow, E. (1994). Nation, Nationalism, National Interests [translation from Russian]. Moscow: Progriess-Kultura.

Skak, M. (2016). Russian Strategic Culture: The Role of Today's 'Chekisty'. Contemporary Politics, 22(3), 324-341. DOI: 10.1080/13569775.2016.1201317. 
Smith, G. (1999). The Post-Soviet States: Mapping the Politics of Transition. London: Edward Arnold.

Snyder, J. (1977). The Soviet Strategic Culture: Implications for Limited Nuclear Operations. Santa Monica: RAND Corporation.

Van Herpen, M.H. (2015). Putin's Propaganda Machine: Soft Power and Russian Foreign Policy. Lanham: Rowman \& Littlefield Publishers.

Wendt, A. (1992). Anarchy Is What States Make of It: The Social Construction of Power Politic. International Organization, 46(2), 391-426.

Wierzbicki, A. (2000). Odcienie rosyjskiego nacjonalizmu. Polityka Wschodnia, 1, 35-68. Wierzbicki, A. (2008). Procesy etnopolityczne w okresie rządów Władimira Putina. In: A. Stępień-Kuczyńska, \& S. Bieleń (eds.), Rosja w okresie prezydentury Władimira Putina (pp. 167-202). Toruń: Adam Marszałek.

Zieliński, E. (2005). System konstytucyjny Federacji Rosyjskiej. Warszawa: Wydawnictwo Sejmowe. 